\title{
State of the Art of Anti-Inflammatory Drugs
}

\author{
Túlio Ricardo Couto de Lima Souza, Graziella Silvestre Marques, \\ Amanda Carla Quintas de Medeiros Vieira \\ and Juliano Carlo Rufino de Freitas \\ Universidade Federal de Pernambuco \\ Brazil
}

\section{Introduction}

The steroidal and non-steroidal anti-inflammatory drugs are known to be among the most commercialized drugs worldwide, however several discussions have been raised about its side effects, caused especially in the chronic use. In this context, the discovery of new prototypes with improved anti-inflammatory activity and therapeutic safety is one of the targets in the area of research, development and innovation of the pharmaceutical industry.

The intensive search for new anti-inflammatory therapeutic options with effective therapies and fewer adverse effects resulted in the development of non-steroidal anti-inflammatory drugs (NSAIDs) with selective inhibition of cyclooxygenase-2 (coxibs). This new generation of drugs came to market due to their greater efficiency and minor capacity to damage gastric and renal sites compared to non-selective NSAIDs. This advantage would be pharmacodynamically explained by its ability to selectively inactivate the inducible cyclooxygenase-2 (COX-2), the enzyme that induces prostaglandin synthesis at the inflammation site, preserving the constitutive cyclooxygenase-1 (COX-1) responsible for physiological protection carried by prostaglandins in those sites. Despite the therapeutic efficiency, some of the developed coxibs has been removed from the market by causing significant cardiovascular effects.

Thus, efforts are still underway to discover new anti-inflammatory chemical entities. Several studies have been conducted with synthetic agonists (thiazolidinodiones) of a biological anti-inflammatory target discovered in the nineties, the peroxisome proliferator activated receptor $\gamma(\mathrm{PPAR} \gamma)$. The research of drugs with anti-inflammatory activity carried out by different mechanisms of action from the conventional ones is extremely important in an attempt to expand the therapeutic options for patients who have restrictions on the use of the available anti-inflammatory drugs.

\subsection{History}

The hability to treat fever and inflammation dates back to 2500 years ago (400 B.C.) to a time when the Greek physician Hippocrates prescribed an extract from willow bark and leaves (Rao \& Knaus, 2008). Later, in 1860, with the discovery of the active ingredient of willow bark salicin in Europe, the Kolbe company in Germany started mass producing salicylic 
acid. Acetysalicylic acid (Aspirin $\left.{ }^{\circledR}\right)$, the more palatable form of salicylic acid was introduced into the market by Bayer in 1899 (Vane, 2000).

In the 1930s and 1940s, numerous developed studies allowed the recognition of the effects of adrenocortical hormones on electrolyte balance (mineralocorticoids effects) and carbohydrate metabolism (glucocorticoids effects). In 1946, cortisol was synthesized, and in 1948, first used by Hench in patients with rheumatoid arthritis. In the 1950s, changes in the structure of cortisol resulted in new drugs such as prednisone and prednisolone. Later, the side effects related to the use of these therapies have been recognized, adding limitations to the therapeutic use of glucocorticosteroids.

In 1946 was brought to the market phenylbutazone, the first drug other than Aspirin ${ }^{\circledR}$ of the category of what are now known as the NSAIDs, followed by indomethacin in the 1960's (by Merck \& Co). In the 1950-1960's Ibuprofen was developed by Boots (UK), and it was the first NSAID (other than Aspirin ${ }^{\circledR}$ ) to be approved for non-prescription use in the UK (1963), then USA (1964), and later in many other countries worldwide. Just after the advent of Ibuprofen, in the seventies John Vane discovered the mechanism of action of Aspirin ${ }^{\circledR}$ and other NSAIDs: the inhibition of cyclooxygenase (COX) enzyme (Vane, 1971). After that, a large number of pharmaceutical companies undertook the discovery and development of many other NSAIDs.

In the early 90's there was reported the presence of an inducible isoform of the COX enzyme, later identified as COX-2 (Kujubu \& Herschman, 1992). This discovery led to the hipothesis that the non-inflammatory prostaglandins were produced by the constitutive COX-1 and pro-inflammatory prostaglandins by the non-constitutive COX-2 (Meade et al., 1993). The conventional anti-inflammatory drugs were known to inhibit both isoforms of the enzyme. The COX-1 inhibition would explain the gastrointestinal adverse effects caused by the NSAIDs. In an attempt to research new therapeutic agents with fewer adverse effects, the pharmaceutical companies focused their efforts on the design of selective COX-2 inhibitors. In 1999, G.D. Searle and Pfizer (now Pfizer Inc) launched the first selective COX-2 inhibitor, celecoxib (Celebrex ${ }^{\circledR}$ ) (Rao \& Knaus, 2008). This was followed by the launch of Merck's rofecoxib (Vioxx ${ }^{\circledR}$ ) and other coxibs (Prasit, 1999).

The research and development of new therapies to treat inflammation, pain and arthritis is still a constant in the pharmaceutical industry. Between 1999 and 2010, at least 12 arthritis and inflammation related new chemical and biological entities were released, 5 of them antiinflammatory agents. However, rofecoxib (Vioxx ${ }^{\circledR}$ ) and valdecoxib (Bextra ${ }^{\circledR}$ ) were still withdrawn from the market due to the high cardiovascular risk related to its use (United States Food and Drug Administration [FDA], 2011).

\subsection{Anti-Inflammatory use and market}

The anti-inflammatory class of drugs is among the most widely prescribed groups of medicines in clinical practice worldwide. The global market for treatment of pain in 2009 amounted to US\$ 50 billion, of which 27 billion in the seven largest economies (USA, Japan, France, Germany, Italy, Spain and UK). Of these US\$ 27 billion, NSAIDs constitute $28 \%$ NSAIDs and selective COX-2 inhibitors 7\% (Melnikova, 2010). Other data that brings the high use of anti-inflammatory drugs reveal that 40 thousand tons of acetyl-salicylic acid are ingested every year around the world (Menezes et al., 2009), besides the large number of 
NSAIDs available for purchase in the market, many of them obtained without prescription. This fact can explain the high cash income derived from the NSAIDs prescription.

Recently, a study carried out in six European countries showed an increase in the use of anti-inflammatory drugs during the 2002-2007 period. It is important to emphasize that during this period the use of conventional NSAIDs increased by $2.07 \%$, while the stronger COX-2 inhibitors use increased by 325\% (Inotai et al., 2010).

The numbers regarding the use of corticosteroids as anti-inflammatory therapy in the U.S. shows that each year approximately 67 million prescriptions are written, despite their multiple side effects. In 2007, the combined annual sales for corticosteroids totaled about US\$ 7.4 billion, not including generics (Hollis-Eden Pharmaceuticals, 2007).

Associated with these high values regarding anti-inflammatory therapies, there are other ones related to its adverse effects. Some studies developed at the US showed that, for each dollar spent on NSAIDs, from U\$0.66 to U $\$ 1.25$ may be spent due to gastrointestinal adverse effects. Aditionally, almost $1 / 3$ of the medical costs in arthritis patients may be related with gastrointestinal effects (Laine et al., 2010).

\subsection{Physiopathology}

Acute inflammation may be triggered by a variety of stimuli and is characterized by the rapid host response to the sites of infection or tissue injury, with the delivery of leukocytes and plasma proteins, such as antibodies, to the referred site. Chronic inflammation may develop following acute inflammation and may last for weeks or months, and in some instances for years.

During both acute and chronic inflammatory processes, a number of soluble factors are involved in leukocyte recruitment through increased expression of cellular adhesion molecules and chemoattraction. Through this mechanism, many soluble mediators regulate the activation of resident cells, such as endothelial cells, fibroblasts, tissue macrophages and mast cells, as well as newly recruited inflammatory cells such as monocytes, lymphocytes, neutrophils and eosinophils. Some of these mediators result in the systemic inflammatory responses, as fever, hypotension, the synthesis of acute phase proteins, leukocytosis and cachexia (Feghali \& Wright, 1997).

Some transcription factors play a significant role in the inflammatory process. In this context, an important one is Nuclear Factor-kappa B (NF-kB), which controls the transcription of DNA (Gilmore, 2006). Activation of the NF-kB transcription family, by nuclear translocation of cytoplasmic complexes, plays a central role in inflammation through its ability to induce transcription of proinflammatory genes and consequently mediators like cytokines and chemokines, matrix metalloproteinases (MMPs), COX-2, and inducible nitric oxide (iNOS) (Baldwin, 1996). NF-kB activation also increases expression of the adhesion molecules E-selectin, vascular cell adhesion molecule 1 (VCAM-1), and intercellular adhesion molecule 1 (ICAM-1), while inhibition reduces leukocyte adhesion and transmigration (Chen et al., 1995). The activity of NF-kB is tightly regulated by interaction with inhibitory IkB proteins (Gilmore, 2006).

The mediators that act in the inflammatory process can be divided in cell-derived and plasma protein-derived. These include: 
- Cell-derived: Histamin, Serotonin, Prostaglandins, Leukotrienes, Platelet-activating factor, Reactive oxygen species, Nitric oxide, Cytokines (tumor necrosis factor - TNF, interleukin-1 - IL-1), Chemokines;

- Plasma-protein derived: Complement products (C3a, C4a, C5a), Kinins, Proteases activated during coagulation.

Among the mediators of inflammation many are derived from the arachidonic acid. The scheme below shows the biochemical cascade that leads to some of them (Figure 1):

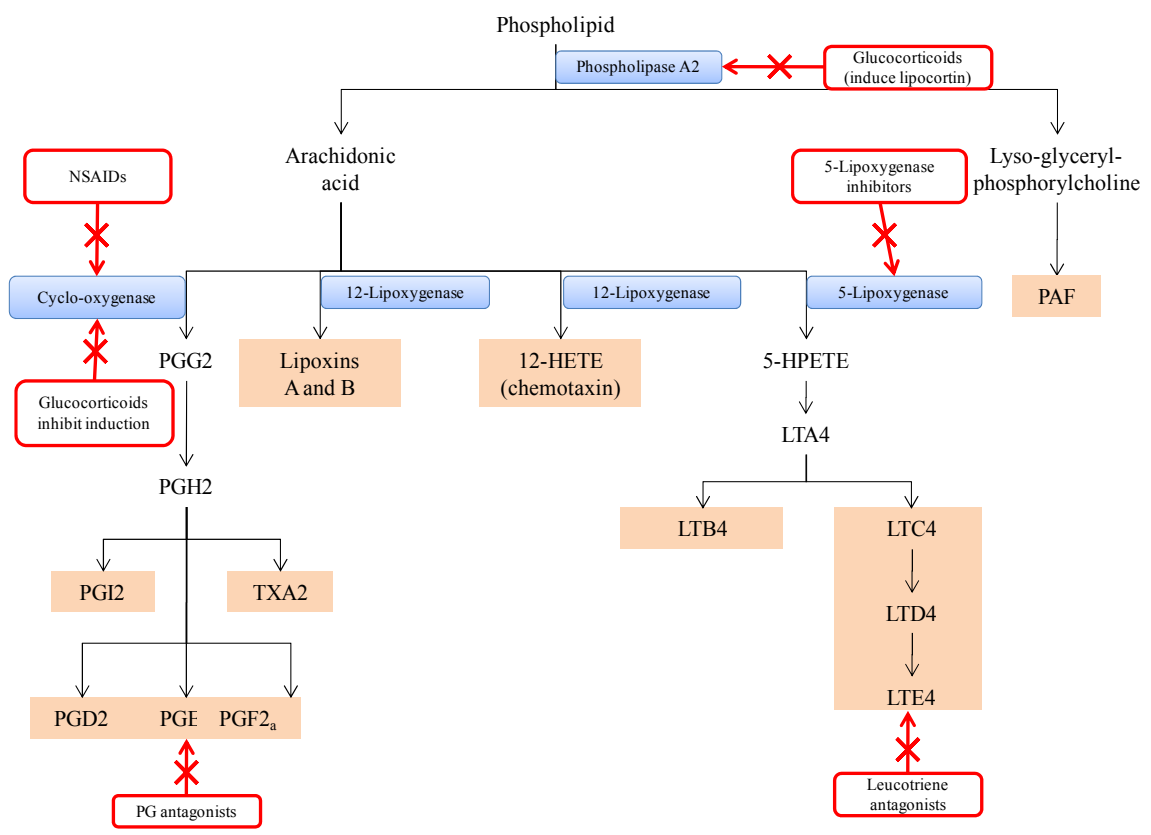

Fig. 1. The arachidonic acid cascade leads to a number of mediators of inflammation. As indicated in red, many steps of this cascade are potential anti-inflammatory targets, such as enzymes and eicosanoids receptors. In this chapter, will be discussed the NSAIDs and glucocorticosteroids. PAF, platelet-activating factor; PG, prostaglandin; 12-HETE, $12-$ hydroxyeicosatetraenoate; 5-HPETE, 5-hydroperoxyeicosatetraenoate; TXA2, thromboxane A2; LT, leukotriene.

The classic anti-inflammatory therapies are based on the inhibition of the cyclooxygenase enzymes (NSAIDs) and cyclooxygenase 2 expression (glucocorticosteroids), thus preventing the prostanoids to be generated and on the phospholipase A2 enzyme expression inhibition (glucocorticosteroids), inhibiting the whole arachidonic acid cascade. Moreover, corticosteroids induce key anti-inflammatory genes and selectively repress specific inflammatory genes that encode a number of other mediators of inflammation, consequently inhibiting the inflammatory response. The anti-inflammatory response of these medicines can be explained by the reduction of the inflammatory response of such mediators, once its generation is decreased by the action of the medicines. Many side effects experienced by these drugs users can be explained by the absent physiological role of these mediators (Table 1). 


\begin{tabular}{|c|c|c|c|}
\hline $\mathrm{PGI}_{2}$ & $\mathrm{PGD}_{2} \& \mathrm{PGF}_{2 \alpha}$ & $\mathrm{PGE}_{2}$ & $\mathrm{TXA}_{2}$ \\
\hline $\begin{array}{l}\text { Platelets: Inhibits } \\
\text { platelet aggregation } \\
\text { and disaggregates } \\
\text { preformed clumps. } \\
\text { Limits platelet } \\
\text { activation by TxA }{ }_{2} \\
\text { reducing the } \\
\text { thrombotic response } \\
\text { to vascular injury. } \\
\text { Kidneys: Maintain } \\
\text { renal blood flow and } \\
\text { salt excretion. PGI2 } \\
\text { promotes renin release } \\
\text { and natriuresis via } \\
\text { effects on tubular } \\
\text { reabsorption of } \mathrm{Na}^{+} \text {. }\end{array}$ & $\begin{array}{l}\text { Vascular smooth } \\
\text { muscle }\left(\mathrm{PGF}_{2 \alpha}\right) \text { : } \\
\text { Vasoconstriction; } \\
\text { Uterus: Relaxation } \\
\left(\mathrm{PGD}_{2}\right) \text { and } \\
\text { contraction }\left(\mathrm{PGF}_{2 \alpha}\right) .\end{array}$ & $\begin{array}{l}\text { Pregnancy: COX-2-derived } \mathrm{PGE}_{2} \\
\text { maintains the ductus arteriosus patent } \\
\text { until birth. Reduced } \mathrm{PGE}_{2} \text { levels permit } \\
\text { closure. Stimulates contraction of the } \\
\text { pregnant human uterus; } \\
\text { Kidneys: Maintain renal blood flow } \\
\text { and salt excretion; } \\
\text { Gastric and intestinal secretions: } \\
\text { Contributes to increased mucus } \\
\text { secretion (cytoprotection), inhibition of } \\
\text { gastric acid secretion, and reduced } \\
\text { pepsin content. Inhibits gastric damage } \\
\text { caused by a variety of ulcerogenic } \\
\text { agents and promote healing of } \\
\text { duodenal and gastric ulcers; } \\
\text { Bones: Stimulates bone formation by } \\
\text { increasing osteoblastogenesis. Bone } \\
\text { resorption also is mediated via PGE } \\
\text { through activation of osteoclasts }\end{array}$ & $\begin{array}{l}\text { Platelets: } \\
\text { Induces platelet } \\
\text { aggregation; } \\
\text { Vascular tone: } \\
\text { Causes } \\
\text { vasoconstriction; } \\
\text { Parturition: } \\
\text { Important in the } \\
\text { final stages of } \\
\text { parturition. }\end{array}$ \\
\hline $\begin{array}{l}\text { Inflammation: } \\
\text { Increases local blood } \\
\text { flow, vascular } \\
\text { permeability, and } \\
\text { leukocyte infiltration } \\
\text { Pain: Reduces the } \\
\text { threshold to } \\
\text { stimulation of } \\
\text { nociceptors, causing } \\
\text { peripheral sensitization. }\end{array}$ & $\begin{array}{l}\text { Inflammation } \\
\left(\text { PGD }_{2}\right) \text { : Contributes } \\
\text { to inflammation in } \\
\text { allergic responses. } \\
\text { Increases perfusion } \\
\text { and vascular } \\
\text { permeability and } \\
\text { promotes } \mathrm{T}_{\mathrm{H}} 2 \text { cell } \\
\text { differentiation. } \mathrm{PGD}_{2} \\
\text { also can activate } \\
\text { mature } \mathrm{T}_{\mathrm{H}} 2 \text { cells and } \\
\text { eosinophils via its } \\
\mathrm{DP}_{2} \text { receptor. }\end{array}$ & $\begin{array}{l}\text { Inflammation: Increases local blood } \\
\text { flow, vascular permeability, and } \\
\text { leukocyte infiltration } \\
\text { Pain: Reduces the threshold to } \\
\text { stimulation of nociceptors, causing } \\
\text { peripheral sensitization } \\
\text { Fever: } \text { PGE }_{2} \text { can cross the blood-brain } \\
\text { barrier and acts on } \mathrm{EP}_{3} \text { and perhaps } \\
\mathrm{EP}_{1} \text { receptors on thermosensitive } \\
\text { neurons. This triggers the } \\
\text { hypothalamus to elevate body } \\
\text { temperature by promoting an increase } \\
\text { in heat generation and a decrease in } \\
\text { heat loss. }\end{array}$ & $\begin{array}{l}\text { Inflammation: } \\
\text { Increases } \\
\text { platelet- } \\
\text { leukocyte } \\
\text { interaction. }\end{array}$ \\
\hline
\end{tabular}

Table 1. The diverse activities of prostaglandins are reflected by their involvement in both normal homeostasis (blue) and pathophysiology (red). Many of the NSAIDs side effects can be explained by the absent physiological role of prostanoids (renal, cardiovascular, gastrointestinal) due to the COX inhibition (Goodman et al., 2010).

Among the soluble factors that mediate inflammation, a group of secreted polypeptides known as cytokines play essential roles in orchestrating the process. They can be divided into two groups: those involved in acute inflammation and those responsible for chronic inflammation (See Figure 2 and Table 2).

The most important cytokines involved in inflammatory reactions are listed. In this context, TNF- $a$ and IL-1 are important in developing the acute and sustaining the chronic inflammatory process (O'Neill, 2008). Working in concert with each other and various cytokines and growth factors (such as IL-6, IL-8 and granulocyte-macrophage colonystimulating factor [GM-CSF]), they induce gene expression and protein synthesis (including expression of COX-2, adhesion molecules, and acute-phase proteins) in a range of cells to mediate and promote inflammation. Other cytokines may play lesser roles in inflammation. 


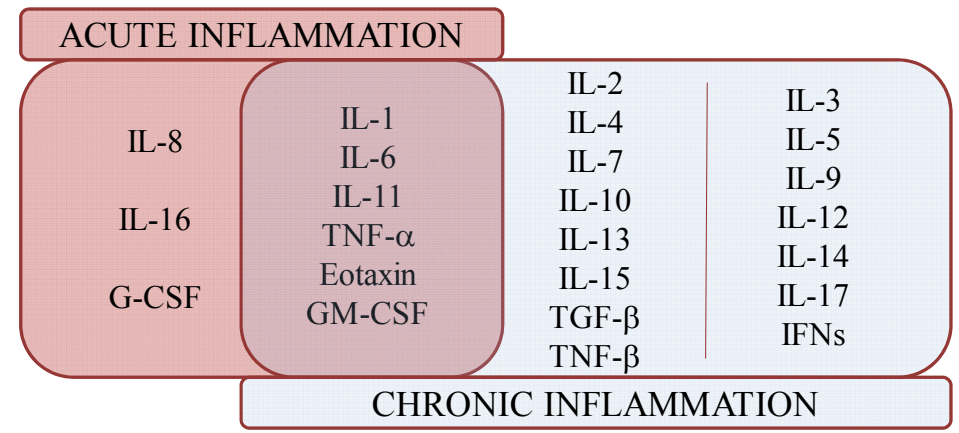

Fig. 2. Cytokines involved in acute and chronic inflammatory responses. IL, interleukin; TNF, tumor necrosis factor; GM-CSF, Granulocyte-colony stimulating factor; TGF, Transforming growth factor; IFN, interferon.

\begin{tabular}{|c|c|c|}
\hline $\begin{array}{l}\text { Principal } \\
\text { cytokines }\end{array}$ & Principal sources & Principal actions in inflammation \\
\hline TNF & $\begin{array}{l}\text { Mast Cells, Macrophages, } \mathrm{T} \\
\text { lymphocytes }\end{array}$ & $\begin{array}{l}\text { Stimulates expression of endothelial } \\
\text { adhesion molecules and secretion of other } \\
\text { cytokines; systemic effects }\end{array}$ \\
\hline IL-1 & Macrophages, endothelial cells & Similar to TNF; greater role in fever \\
\hline IL-6 & Macrophages, other cells & Systemic effects \\
\hline IL-12 & Dendritic cells, macrophages & Increased production of IFN- $\gamma$ \\
\hline IL-17 & T-Lymphocytes & Recruitment of neutrophils and monocytes \\
\hline Chemokines & $\begin{array}{c}\text { Macrophages, endothelial cells, } \mathrm{T} \\
\text { lymphocytes, mast cells, other cell } \\
\text { types }\end{array}$ & $\begin{array}{c}\text { Recruitment of leukocytes to sites of } \\
\text { inflammation; migration of cells to normal } \\
\text { tissues }\end{array}$ \\
\hline IFN- $\gamma$ & T lymphocytes, NK cells & $\begin{array}{l}\text { Activation of macrophages (increased } \\
\text { ability to kill microbes and tumor cells) }\end{array}$ \\
\hline
\end{tabular}

Table 2. Principal cytokines in inflammation (Robbins et al., 2010). NK, natural killer.

The extravasion of leukocytes is controlled by the expression of cell surface adhesion molecules on both the circulating cells and on the vascular endothelium. The TNF- $\alpha$ signaling pathway, mediated by NF- $\mathrm{kB}$, is responsible for the expression of adhesion molecules such as VCAM-1 and ICAM-1 in the endothelium (Collins et al., 1995). TNF-a was previously shown to induce ICAM-1 expression (Fingar et al., 1997). These adhesion molecules allow the attachment of leukocytes to the endothelium and may permit their subsequent transmigration into peripheral tissue. At the same time, microvascular permeability is increased (Frank \& Lisanti, 2008).

\section{Non-Steroidal Anti-Inflammatory Drugs (NSAIDs)}

The NSAIDs are a heterogeneous group of molecules that share certain therapeutic actions and side effects. The first drug belonging this class, Aspirin ${ }^{\circledR}$, was introduced to the market in 1899. After that, several other anti-inflammatory drugs were introduced over the years, until the discovery of selective inhibitors of COX-2, called coxibs. Both traditional NSAIDs and the recent coxibs are effective anti-inflammatory agents and analgesics. However, in 
recent years it has been questioned the safety associated with the use of these drugs in clinical practice, due to the range of side effects caused due to consumption of these drugs, many times inappropriately.

\subsection{Mechanism of action}

The anti-inflammatory action of NSAIDs can be explained by the effect of inhibiting the enzyme COX, which is responsible for the synthesis of prostaglandins, mediators with a great ability to induce inflammation (Tanaka et al., 2009). COX has two isoforms: COX-1 and COX-2. The first is constitutively expressed in a wide variety of cells, promoting physiological functions, such as gastric mucosal protection, control of renal blood flow, hemostasis, autoimmune responses, lungs, central nervous system, cardiovascular system and reproductive functions (Grosser et al., 2006).

On the other hand, COX-2 is an inductive enzyme, which is expressed significantly due to various stimuli such as cytokines, endotoxins and growth factors. COX-2 originates inducing prostaglandins, which contribute to the development of the four cardinal signs of inflammation: pain, heat, redness and swelling (Fitzgerald, 2004), thus being considered as the main target for the anti-inflammatory action. In this context, the recently developed coxibs act through selective inhibition of COX-2. However, although inductive, this COX isoform is also expressed in normal vascular endothelial cells, synthesizing prostacyclin, an important substance in maintaining the prothrombotic/antithrombotic blood balance (Antman et al., 2007), which can trigger severe cardio-vascular problems.

\subsection{Therapeutic uses}

The effects of inhibiting the COX enzyme explain the clinical uses of the NSAIDs (including selective COX-2 inhibitors), mainly as antipyretics, analgesics and anti-inflammatory agents.

- Inflammation: As anti-inflammatory agents, are used to treat muscle injuries, tendinitis, bursitis and in relieving postoperative pain, in addition to its indication for chronic rheumatic diseases such as rheumatoid arthritis, osteoarthritis, gouty arthritis and ankylosing spondylitis (Pountos et al., 2011). In the latter cases, NSAIDs are often associated with disease modifying anti-rheumatic drugs (DMARDs), so that in addition to reducing pain and discomfort of the patient, also promote the regression of the disease.

- Pain: Its use as analgesic is indicated for relieving mild to moderate pain. They are particularly effective when inflammation has caused peripheral and/or central sensitization of pain perception. Thus, postoperative pain or pain arising from inflammation, such as arthritic pain, is controlled well by NSAIDs, whereas pain arising from the hollow viscera usually is not relieved (Goodman et al., 2010).

- Fever: NSAIDs are thought to be antipyretic largely through inhibition of prostaglandin production in the hypothalamus. They can reduce fever in most situations, but not the circadian variation in temperature or the rise in response to exercise or increased ambient temperature. McAdam et al. (1999), in a comparative study of the impact of non-selective NSAIDs and selective COX-2 inhibitors, suggested that COX-2 is the main source of PGs that mediate the rise in temperature caused by bacterial lipopolysaccharide (LPS) administration. 
- Cardioprotection: The suppression of platelet TxA2 formation promotes the cardioprotective effect of aspirin. It is used as an antiplatelet drug, in the management of the myocardial infarction and in angina, reducing the risk of serious vascular events in high-risk patients (e.g., those with previous myocardial infarction) by $20-25 \%$. Lowdose ( $<100 \mathrm{mg} /$ day) aspirin, is as effective as higher doses (e.g., $325 \mathrm{mg} /$ day) but is associated with a lower risk for gastrointestinal adverse events (Goodman et al., 2010).

- Cancer Chemoprevention: Studies of patients with familial adenomatous polyposis and Gardner's syndrome (Waddell et al., 1983, 1989) introduced the idea that NSAIDs may inhibit cancer progression. Cha \& Raymond (2007) found that in colorectal cancers the same occurs because COX-2 is selectively upregulated, which was subsequently found to be elevated in other epithelial tumors including breast, stomach, pancreas, bladder, lung and prostate cancers. Since the NSAID action is inhibition of the enzymatic activities of COX-1 and COX-2, it was hypothesized that the beneficial effect of NSAIDs was due, in part, to inhibition of COX-2 in the tumor microenvironment. Additionally, recent clinical trials clearly demonstrate that celecoxib is very effective in reducing polyp recurrence in patients who have undergone a polypectomy (Arber et al.; Bertagnolli et al., 2006). This drug is particularly effective in reducing recurrence of very large polyps, which are more likely to progress into cancer. Recently, a new group of NSAIDs have been explored for their effectiveness in several diseases, such as cardiovascular, rheumatological and lung diseases, Alzheimer's disease, and cancer: the Nitric oxide-donating nonsteroidal antiinflammatory drugs (NO-NSAIDs). These drugs consist of a traditional NSAID to which a NO releasing moiety is covalently attached, and may have an important role in colon cancer prevention and/or treatment (Yeh et al., 2004).

- Alzheimer's Disease: Observational studies have suggested that NSAID use, in particular ibuprofen, is associated with lower risk of developing Alzheimer's disease. The same was not observed when a randomized, controlled clinical trial comparing celecoxib, naproxen, and placebo (ADAPT Research Group, 2008) was performed, where the researchers did not find a significant reduction in Alzheimer's dementia with the use of NSAIDs.

- Other Clinical Uses: In patients with systemic mastocytosis, PGD2, released from mast cells in large amounts, has been found to be the major mediator of severe episodes of flushing, vasodilation, and hypotension. The addition of aspirin or ketoprofen has provided relief (Worobec, 2000). Large doses of niacin (nicotinic acid), effectively used to lower serum cholesterol levels, reduce low-density lipoprotein, and raise high-density lipoprotein, can induce intense facial flushing. This flushing is mediated largely by release of PGD2 from the skin, which can be inhibited by treatment with aspirin (Jungnickel et al., 1997). Bartter syndrome includes a series of rare disorders characterized by hypokalemic, hypochloremic metabolic alkalosis with normal blood pressure and hyperplasia of the juxtaglomerular apparatus. Renal COX-2 is induced, and biosynthesis of PGE2 is increased. Treatment with indomethacin, combined with potassium repletion and spironolactone, is associated with improvement in the biochemical derangements and symptoms. Selective COX-2 inhibitors also have been used (Guay-Woodford, 1998).

\subsection{Side effects}

The use of NSAIDs has been associated with a high number of side effects. Thus, the prescription of these drugs should be made through a previous study of the individual patient, 
taking into account the required dosage and the use of other drugs, in order to understand the patient risk-benefit relation. The most prominent side effects are described below:

- Gastrointestinal effects: Several prostanoids, especially prostacyclin and PGE 2, are crucial to protect the gastric mucosa from the corrosive effects of stomach acid, as well as to maintain the naturally healthy condition of the gastric mucosa (Antman, 2007). Therefore, the consequences of inhibition of COX-1 may lead to the triggering of various side effects ranging from nausea to bleeding ulcers, which can lead the user to death (Pountus et al., 2011). The use of high doses or the prolonged consumption of NSAIDs, along with its administration with corticosteroids and/or anticoagulant drugs, smoking and/or alcohol, increases the probability of experiencing these effects. However, some in vitro studies reported that there is a relationship between the besides the NSAIDs and COX adversities stomach: Some drugs shown to have direct cytotoxic action on cells of the gastric mucosa, may also be the reason of such effects (Siew \& Francis, 2010).

- Cardiovascular effects and the coxibs: Some prostaglandins and other substances produced by COX regulates complex interactions between platelets and the blood vessel walls. In this context, prostacyclin, a substance produced by COX-2, antagonizes the action of platelet aggregation by interacting with its receptor IP. However, platelets contain only one isoform of COX, able to convert a large quantity of arachidonic acid to a potent aggregating agent, thromboxane A2 (TXA2). Therefore, with the administration of selective COX-2 drugs (coxibs), an imbalance can occur in the production of prostacyclin and TXA2, reflecting in a prothrombotic/antithrombotic blood imbalance and a consequent increase in risk of thrombotic events (Topol, 2004; Antman et al., 2005). In this context, the studies of Grahamm and coworkers (2005) showed an increase of 1.49 times in the risk of acute myocardial infarction patients for consuming rofecoxib at a dose of $25 \mathrm{mg} /$ day (maximum dose chronic allowed) in a three years period. Additionally, the author noticed an increase of 3.58 times in this risk with the consumption of doses greater than $25 \mathrm{mg} /$ day of celecoxib. A number of other studies reported a significant increase in the risk of developing acute myocardial infarction associated with the use of such medicines (Bresalier et al., 2005). Given these results, the Food and Drug Administration (FDA) has formalized the limited use of these drugs. Two of them (rofecoxib and valdecoxib) were still withdrawn from the market (United States Food and Drug Administration [FDA], 2011).

- Erectile dysfunction: Inhibition of prostaglandin synthesis and TXA2 by NSAIDs may interfere with the physiological process of penile erection through nitric oxide, which is an essential physiological signal for penile erection (Shiri et al., 2006). According to the study of Shiri and coworkers, 2006, Erectile dysfunction is related to the used therapy, regardless the incident disease. The author of the study showed that the onset of the erectile dysfunction in patients with arthritis treated with NSAIDs was lower than expected in the use of the drug in the absence of a disease, indicating a negative function between the use of NSAIDs in arthritis and the risk of developing the disorder. In addition, the study concluded that it is a reversible process, with enhanced sexual performance when the drug is discontinued.

- Nephrotoxicity: Inhibition of COX-1 results in declining levels of renal vasodilatory prostaglandins, which among other effects, maintains renal blood flow and glomerular filtration rates. This effect is mainly exerted by them relaxing preglomerular resistance 
and acting as angiotensin II and norepinephrine antagonists. Aditionally, they cause an increase in organ perfusion and reduction in the release of noradrenaline. In this context, the inhibition of such mechanisms tends to decrease the total renal perfusion and redistribute blood flow to the cortex, especially when there is stimulation of the reninangiotensin-aldosterone system and/or stimulation of the sympathetic nervous system. Such processes may result in acute renal vasoconstriction, medullar ischemia, and under certain conditions, acute renal failure. Therefore, the use of NSAIDs may result in varying degrees of renal dysfunction, ranging from the reversible commitment of glomerular filtration rate to irreversible renal damage (Winkelmayer et al. 2008; Pountos, 2011).

\subsection{Contra-indications}

The contraindications for NSAIDs are quite understandable and are closely related to its adverse effects. The FDA proposes the contraindications for hypertensive patients, patients with chronic renal, cardiovascular and gastroesophageal diseases (Keenan et al., 2011).

Additionally, there is not a clear dividing line for the clinical use of NSAIDs and their toxicology, where it is necessary the cautious interpretation of clinical risk factors. Such factors may increase the likelihood of developing these side effects, and are described in Table 3 (Holdgate \& Pollock, 2004; Berenbaum, 2004).

\begin{tabular}{|c|c|}
\hline \multicolumn{2}{|r|}{ Risk factors related to the consumption of NSAIDs } \\
\hline Patient & Older than 65 years, consumption of alcohol and/or smoke. \\
\hline Clinical History & $\begin{array}{c}\text { Gastrointestinal (GI) events or ulcers, prior induction of GI events by NSAIDs } \\
\text { consumption, comorbid conditions, poor functional status. }\end{array}$ \\
\hline Drug & Chronic use, high doses, concomitant use with other NSAIDs. \\
\hline
\end{tabular}

Table 3. Risk factors related to the use of NSAIDs (Pountos et al., 2011).

Several studies include pregnant and lactating women in the clinical contraindicated profile, which culminated in a warning issued by the Adverse Drug Reactions Advisory Committee (ADRAC) in 1991. It emphasized the congestive heart failure and poor prognosis risks related to the use of NSAIDs during pregnancy (Hofstadler et al., 1996), reporting cases of premature closure or constriction of the ductus arteriosus in women with diclofenac, indomethacin and mefenamic acid treatment due to low back pain, premature labor and polyhydramnios, respectively.

\subsection{Drug interactions}

Some studies report that the administration of traditional NSAIDs concomitantly with Aspirin ${ }^{\circledR}$ may antagonize its antiplatelet action, compromising its cardioprotective function (Kurth et al., 2003). Additionally, the combination of NSAIDs and coxibs with low-dose Aspirin ${ }^{\circledR}$ significantly increases the likelihood of gastroinestinais adverse events compared with the isolated use of any NSAID (Gladding et al., 2008).

The combined therapy of these drugs with angiotensin-converting enzyme (ACE) inhibitors can cause renal failure (Seeling et al., 1990), commonly seen in elderly patients. The same results from the attenuation of the effectiveness of ACE inhibitors due to the blocked production of vasodilator and natriuretic prostaglandins by NSAIDs. The drug interaction 
also occurs with thiazide diuretics, which can cause impaired renal function and electrolyte imbalance (Secoli, 2010).

Although they are often used to treat rheumatoid arthritis and cancer, the concomitant use of NSAIDs and methotrexate leads to drug interaction, increasing the blood concentration and time of excretion of methotrexate. According to Maeda et al., 2008, there is a competition for the renal transporter, the main route of elimination of methotrexate.

NSAIDs also present interactions with alcohol. Studies have demonstrated that this interaction causes the prolongation of the bleeding mediated by Aspirin ${ }^{\circledR}$ when administered concomitantly. This mechanism is not yet well understood, but some in vitro studies show that this relationship arises from the increase in the inhibiting power of prostacyclin on platelet aggregation (Jakubowski et al., 1988).

\subsection{Main categories of NSAIDs}

- Salicylates: Aspirin ${ }^{\circledR}$ is the pioneer of this class of anti-inflammatory drugs. It is often used for prophylaxis of cardiovascular events at a dosage of 40 to $80 \mathrm{mg} /$ day. Additionally, it has analgesic action and antipyretic in the dosage of 325 to $650 \mathrm{mg}$ every 4 to 6 hours. At a dosage of $1 \mathrm{~g}$ every 4 to 6 hours is indicated for the treatment of rheumatic fever. The dosage for children is changed, being $10 \mathrm{mg} / \mathrm{kg}$ every 4 to 6 hours. Diflunisal $^{\circledR}$ (difluorophenyl) has about 4 to 5 times more analgesic and antiinflammatory power than Aspirin ${ }^{\circledR}$. However, its antipyretic effect is reduced. The administration of diflunisal is performed at doses of 250 to $500 \mathrm{mg}$ every 8 to 12 hours. It presents fewer side effects on platelets and the gastrointestinal tract. Its excretion can be achieved through breast milk, being contraindicated for pregnant women.

- Para-aminophenol derivatives: Acetaminophen or Paracetamol has effective analgesic and antipyretic activity, but its anti-inflammatory activity is insufficient. It is used at a dosage of 10 to $15 \mathrm{mg} / \mathrm{kg}$ every 4 hours, not exceeding the maximum of 5 doses every 24 hours. High doses of acetaminophen cause the production of toxic metabolites and hepatic necrosis.

- Acetic acid derivatives: Indomethacin is 10 to 40 times more potent than salicylic acid. Its peak blood concentration is reached 1-2 hours after administration. It is used at a dosage of $25 \mathrm{mg} 2-3$ times/day or 75 to $100 \mathrm{mg} /$ night. Its side effects affect 30 to $50 \%$ of users, characterized by frontal headache, neutropenia and thrombocytopenia. About $20 \%$ of patients discontinue the therapy. Fenamates have similar effectiveness compared to acetylsalicylic acid, but isolated cases of hemolytic anemia have been reported. Its side effects can reach about $25 \%$ of users. Tolmetin, a heteroaryl acetate derivative, also has similar effectiveness compared to Aspirin ${ }^{\circledR}$. It is used at a dose of 400 to $600 \mathrm{mg}$, three times a day, and $20 \mathrm{mg} / \mathrm{kg} /$ day for children, in 3 to 4 fractionated doses. The absorption of Tolmetin is delayed and decreased in the presence of food. The interruption of therapy occurs in $5-10 \%$ of patients. Diclofenac, a phenylacetate derivative, is administered in doses of $50 \mathrm{mg}$ three times daily or $75 \mathrm{mg}, 2$ times a day. It is more potent than Aspirin ${ }^{\circledR}$, but $20 \%$ of patients develop side effects, $2 \%$ discontinue the use and $15 \%$ develop elevation of liver enzymes.

- Propionic acid derivates: In general, they are better tolerated than Aspirin ${ }^{\circledR}$, with equivalent to or higher power than the same. Ibuprofen is widely used in clinical practice, and presents a large potential to cause renal toxicity. About 10 to $15 \%$ of users 
discontinue treatment due to adverse effects. It is administered at a dose of 200 to $400 \mathrm{mg}$ every 4 to 6 hours for analgesia, whereas for anti-inflammatory the dosage is $300 \mathrm{mg}$ every $6-8 \mathrm{~h}$ or 400 to $800 \mathrm{mg}$ three to four times a day. The dosage for antiinflammatory for children decreases to 5 to $10 \mathrm{mg} / \mathrm{kg}$ every $6 \mathrm{~h}$, with the maximum dose of $40 \mathrm{mg} / \mathrm{kg} /$ day. In children, anti-inflammatory action is achieved with dosages of 20 to $40 \mathrm{mg} / \mathrm{kg} /$ day in 3 to 4 fractionated doses. Naproxen has a long half-life of 14 hours, and can provide cardioprotection in some patients. It is used in the maximum daily dose of $1000 \mathrm{mg}$ being $250 \mathrm{mg} 4$ times daily or $500 \mathrm{mg}$ two times a day. For children, anti-inflammatory dosage is reduced to $5 \mathrm{mg} / \mathrm{kg}$, two times a day. In elderly patients, the drug has lower protein binding and delayed excretion, increasing the likelihood of toxicity in these patients. In the case of fenoprofen, the dosage is 200mg 4-6 times a day. About $15 \%$ of users experience side effects, but few discontinue use. Drugs with high half-life, as oxaprozin (40 to 60h) allows administration once daily. However, it is indicated for fever or acute analgesia because the onset of action is slow. Oxaprozin is used in dosage from 600 to $1800 \mathrm{mg} /$ day.

- Enolic acid derivates: This class is constituted by piroxicam, meloxicam and nabumetone. Both meloxicam and nabumetone have relative selectivity for COX-2. Piroxicam has equivalent power to Aspirin ${ }^{\circledR}$ and is better tolerated. However, it can inhibit the activation of neutrophils and the activity of collagenase and proteoglycanase. This drug is administered in daily doses of $20 \mathrm{mg}$. About $20 \%$ of users develop side effects, while $5 \%$ discontinue the treatment. Nabumetone has fewer side effects than many NSAIDs. Its administration is performed at doses of 500 to $1000 \mathrm{mg}, 1$ to 2 times a day. Meloxicam dosage is 7.5 to $15 \mathrm{mg} /$ day (Goodman et al., 2010).

\section{Glucocorticosteroids (GCs)}

Glucocorticosteroids (GCs) (glucocorticoids; also known as corticosteroids or steroids) are steroid hormones derived from cholesterol metabolism. Their basic molecular structure is the cyclopentanoperhydrophenanthrene, derived from cholesterol.

The natural GC representative is the cortisol or hydrocortisone. They are effective antiinflammatory and immunosuppressive agents, produced naturally in the adrenal gland after stimulation of the hypothalamic-pituitary-adrenal (HPA) (Fernandes et al., 2008; Barnes \& Adcock, 2009). Since the availability of cortisone in the late 1950s, several synthetic GC agonists have been developed, such as prednisone, dexamethasone and betamethasone (Löwenberg et al., 2008). The synthetic GCs are obtained from folic acid (taken from cattle) or some plants of the families Liliaceae and Dioscoreaceae (Timóteo \& Dos Santos, 2008). For decades, they have been among the most commonly prescribed classes of immunomodulatory and anti-inflammatory drugs, being widely used as treatment of choice for several autoimmune and inflammatory diseases, including asthma, rheumatoid arthritis, inflammatory bowel disease and polymyalgia rheumatica. However, serious side effects, such as osteoporosis, skin atrophy, cushingoid appearance, diabetes and glaucoma, frequently accompany GC therapy, which place limitations on the use of higher dosages and long-term use of GCs (Flammer \& Rogatsky, 2008; Löwenberg et al., 2008). Moreover, nowadays, various side effects of glucocorticoids are well-known and physicians often anticipate on these side effects (De Nijs, 2008). 


\subsection{Molecular actions of glucocorticosteroids}

GCs act through many molecular mechanisms. One of them occurs through traditional glucocorticoid receptor mediated pathways to directly regulate gene expression. In this mechanism, the CGs freely diffuses across the cell membrane and act by binding to and activating specific cytosolic glucocorticoid receptors (GR). In its inactive state, the GR exists as a cytosolic protein bound to two heat shock protein 90 chaperonin molecules. The binding to the GC ligand results in a conformational change that allows dissociation of the GR from the protein complex, and a quick translocation into the cell nucleus where they can modulate gene transcription either by stimulation or inhibition (De Paiva \& Pflugfelder, 2008; Barnes \& Adcock, 2009). The glucocorticoid-receptor complex can either induce key anti-inflammatory genes that encode anti-inflammatory molecules (e.g. lipocortin-1, IL-10, IL-1Ra6, TGF- $\beta$ and inhibitory IkB proteins) following direct association with glucocorticoid response elements (GREs) in the promoter regions of these genes, or selectively repress specific inflammatory genes that encode cytokines (e.g. IL-1, IL-6, IL-8, TNF- $\alpha$ ), chemokines, adhesion molecules (e.g. adhesion molecules E-selectin, ICAM-1, VCAM-1), inflammationassociated enzymes (e.g. phospholipase A2, COX-2, iNOS), lipid mediators of inflammation (e.g. prostaglandins) and receptors by protein-to-protein interaction with transcription factors such as the nuclear factor (NF)-KB and activator protein 1 (AP-1), which interact with transcriptional coactivator molecules to activate gene transcription (Derendorf \& Meltzer, 2008; Fernandes et al., 2008). Multiple mechanisms are involved in GC-mediated antiinflammatory activity in addition to direct GR/NF-кB interaction, such as GC-induced upregulation of IKB and glucocorticoid-induced leucine zipper (GILZ), two proteins able to bind and inhibit NF-кB activation (Cuzzocrea et al., 2008).

Furthermore, it has been reported that peroxisome proliferator activated receptor- $\alpha$ (PPARa) can contribute to the anti-inflammatory activity of GCs. PPAR-a is an intracellular transcription factor activated by fatty acids that plays a role in inflammation. Previous studies indicate that PPAR-a expression is induced by GCs and can mediate some of the GC effects, such as modulation of insulin sensitivity and resistance, and can contribute to GCinduced hyperglycemia and blood pressure increase. Moreover, it has been reported that PPAR- $\alpha$ activation can result in inhibition of NF-KB activation and inflammatory gene expression (Cuzzocrea et al., 2008).

\subsection{Therapeutic uses}

- Skin diseases: Several skin diseases are typically treated with systemic or topical GCs. The main indications are psoriasis, contact dermatitis, atopic dermatitis, exfoliative erythroderma, pemphigus vulgaris, pemphigus foliaceus, bullous pemphigoid, cicatricial pemphigoid, gestational herpes, acquired epidermolysis bullosa, linear IgA bullous dermatosis, Stevens Johnson syndrome, toxic epidermal necrolysis, erythema multiforme minor, lupus erythematosus, dermatomyositis, vasculitis, pyoderma gangrenosum, sweet's syndrome, behcet's disease, lichen planus, sarcoidosis and chronic urticaria (Pereira et al., 2007; Akama et al., 2009). In pediatric dermatology, long-term systemic steroids may be used for the treatment of erythroderma due to atopic eczema, pustular psoriasis, childhood pemphigus, chronic bullous dermatosis of childhood, systemic lupus erythematosus, pyoderma gangrenosum or complicated hemangiomas (Deshmukh, 2007). 
- Respiratory tract diseases: Intranasal GCs are effective treatments for allergic rhinitis, rhinosinusitis, and nasal polyposis. They are the most common treatment for patients with nasal polyposis and have been designated as the treatment of choice for allergic rhinitis (Derendorf \& Meltzer, 2008; Zele et al., 2010). The systemic GCs are effective in treating allergic rhinitis, but the high risk of serious toxicity with long-term administration has hindered their usefulness. The first successful use of GC as a pressurized aerosol with no apparent evidence of systemic toxicity was the beclomethasone in 1972. In the following years, corticosteroid molecules have been refined to create more potent agents with lower bioavailability and enhanced safety profiles. Nowadays, various compounds are approved for the management of allergic rhinitis in the United States: triamcinolone acetonide, flunisolide, budesonide, beclomethasone dipropionate, ciclesonide, fluticasone propionate, mometasone furoate, fluticasone furoate (Derendorf \& Meltzer, 2008; Zele et al., 2010). Likewise, GCs are the most effective and widely used anti-inflammatory drugs for the treatment of asthma (Maneechotesuwan et al., 2010; Hagan et al., 2011). The introduction of GCs, in the form of cortisone, for the treatment of asthma more than 60 years ago resulted in pronounced clinical effects. Today, inhaled GCs are considered to be the most effective antiinflammatory treatment, safe in appropriate doses when given to asthmatic children and adults who need regular therapy to control symptoms or prevent exacerbations owing to reduced systemic absorption and risk of systemic side-effects (Rottier \& Duiverman, 2009). Moreover, about $40-50 \%$ of patients with chronic obstructive pulmonary disease are being treated with inhaled GCs (Löwenberg et al., 2008).

- Rheumatologic diseases: Long-term therapy with GCs is often necessary to control the symptoms of rheumatoid arthritis and other rheumatic conditions (Neeck et al., 2002; Paul-Clark et al., 2002). It has been reported that up to $60 \%$ of patients with rheumatoid arthritis are treated more or less continuously with GCs (Löwenberg et al., 2008). Polymyalgia rheumatica is also a common indication for long-term glucocorticoid therapy and has a favorable prognosis. However there is considerable heterogeneity in patients' clinical course and response to this therapy. In addition, the patients are usually maintained on the lowest possible dose to control disease symptoms and to minimize GCs complications (Salvarani et al., 2002; Kremers et al., 2007).

- Gastrointestinal inflammatory diseases: Glucocorticoids are an effective treatment for inflammatory bowel disease such as ulcerative colitis and Crohn's disease (Löwenberg et al., 2008). Crohn's disease is a chronic inflammatory disorder of the bowel whose cause is unknown. During the acute phase of the disease, glucocorticoids such as prednisolone and prednisone are commonly used (Thomsem et al., 1998). In ulcerative colitis prednisolone was found to induce remission of symptoms concomitantly with reduction of endoscopically viewed colonic inflammation (Olaison et al., 1990). However, failure to respond, acutely or chronically, to GC therapy is a common indication for surgery in inflammatory bowel disease, with as many as $20 \%$ of patients with ulcerative colitis and approximately $50 \%$ of patients with Crohn's disease requiring surgery in their lifetime as a result of poor response to medical therapy (Farrell \& Kelleher, 2003).

- Other therapeutic uses: GCs have been successfully used in the management of patients with renal diseases, allergic reactions, thrombocytopenia, corneal epithelial disease in dry eye and Graves' ophthalmopathy (De Paiva \& Pflugfelder, 2008). In addition, these agents play an important role in the treatment of immune disorders, 
including reducing the immune response in autoimmune diseases and organ transplantation (Grbović; Radenković, 2005). In short term, high dose suppressive GC therapy is also indicated in the treatment of medical emergencies such as necrotising vasculitis, status asthmaticus and anaphylactic shock (Swartz; Dluhy, 1978).

\subsection{Side effects and contraindications}

The physiologic effects of GCs are numerous and widespread. They influence electrolyte and water balance, carbohydrate metabolism, protein metabolism, lipid metabolism, cardiovascular system, skeletal muscle, central nervous system (CNS), formed elements of blood and affect other organs and tissues in a wide variety of ways (Chaney, 2002). The effect on fluid and electrolytes is due to their mineralocorticoid effect. It causes salt and water retention leading to edema, weight gain and hypertension. The potassium loss leading to hypokalemia can cause severe weakness (Deshmukh, 2007). Hyperglycemia is a known complication of GC therapy caused mainly by increased hepatic capacity for gluconeogenesis and reduced sensitivity to insulin. This increase in blood sugar levels can be a negative prognostic factor for ill patients (Davenport et al., 2010). Furthermore, GCs also increase lipid levels because of increased lipid production in liver and due to lipolysis from adipose tissue; and cause redistribution of carbohydrate, fat and protein reserves. This along with the increase in appetite can lead to the Cushingoid habitus (moon facies, buffalo hump and central obesity) (Deshmukh, 2007).

Due to these effects in the body, GC therapy is frequently hampered by severe side effects, especially when used in high doses for prolonged durations. The adverse effects of corticosteroids seen during short-term therapy include increased appetite, weight gain, fluid retention, gastritis, headache, mood swings, increase in blood sugar, hypertension and glaucoma. Adverse effects seen when therapy is given for longer duration include suppressed immunity, increased susceptibility to infections, increased cholesterol levels, weight gain, osteoporosis, deposition of body fat, thinning of skin, cataracts, stunting and hypothalamopituitary axis suppression (Löwenberg et al., 2008). Bone loss is one of the most important side effects of GC use. It starts promptly after initiation and mainly takes place in the first six months of treatment. Several studies and reports show a decrease in bone mineral density and an increased risk of fractures during GC use. The main effect of GC on bone is inhibition of osteoblast function, leading to a decrease in bone formation (De Nijs, 2008).

These side effects are responsible for several contraindications and limit the use of higher dosages and long-term use of GCs (Niedner, 2001; Löwenberg et al., 2008) The most important contraindications for the therapy of systemic GCs are uncontrolled hypertension, glaucoma, uncontrolled diabetes mellitus, osteoporosis, acute viral infections, bacterial infections, systemic fungal infections, parasitic diseases and psychiatric history (Niedner, 2001). Thus, the clinician must carefully consider in each case the presence of contraindications and the gains that can reasonably be expected from GC therapy versus the inevitable undesirable side effects of prolonged therapy (Niedner, 2001). The risk of glucocorticoid-induced osteoporosis can be reduced, for example, by general measurements like prescribing GCs in a low dose and for a short period of time. Furthermore, calcium and plain vitamin D3 supplementation and pharmacological intervention with bisphosphonates are considered as important support for prevention and treatment of glucocorticoid-induced osteoporosis (De Nijs, 2008). 


\subsection{Glucocorticosteroid resistance in inflammatory diseases}

GCs resistance or insensitivity is a major barrier to the treatment of several common inflammatory diseases, including chronic obstructive pulmonary disease and acute respiratory distress syndrome; it is also an issue for some patients with asthma, rheumatoid arthritis, and inflammatory bowel disease. The resistance to the anti-inflammatory effects of GCs can be induced by several mechanisms that may differ between patients. These mechanisms include reduced GR expression, altered affinity of the ligand for GR, reduced ability of the GR to bind to DNA, increased expression of inflammatory transcription factors (eg, NF-KB, AP-1), raised macrophage migration inhibitory factor, and increased Pglycoprotein-mediated drug efflux. Patients with GC resistance can be treated with alternative broad-spectrum anti-inflammatory treatments, such as calcineurin inhibitors and other immunomodulators, or novel anti-inflammatory treatments, such as inhibitors of phosphodiesterase 4 or NF-кB (Barnes \& Adcock, 2009).

\subsection{Main glucocorticoid drugs}

Several synthetic GC agonists have been developed since the availability of cortisone in the late 1950s (Löwenberg et al., 2008). The pharmacologic differences among various GCs derivatives result from structural alterations of the basic steroid nucleus and its side groups (Cevc \& Blume, 2004). The main representatives of this class drugs and their peculiarities are described below.

- Hydrocortisone: A steroid hormone secreted by the adrenal cortex, is a short-acting GC (biological half-life of 8-12 hours) available in drug forms as unchanged hormone either different salts thereof (acetate, cypionate, sodium phosphate, butyrate, valerate, and sodium succinate). The hydrocortisone is used orally, in combination with fludrocortisone, for replacement therapy in adrenal insufficiency (Deshmukh, 2007). The effect of this agent on the milk is not known (Damiani et al., 2001). Hydrocortisone sodium succinate, the water-soluble derivative, is administered parenterally for a quicker effect in emergencies (Deshmukh, 2007);

- Prednisone: An intermediate-acting GC (biological half-life of 12-36 hours), is four to five times more potent than hydrocortisone (Zoorob; Cender, 2000). This GC is a prodrug, converted in normal circumstances in the body to prednisolone. It's widely used orally in the acute and long-term management of various disorders and for antiinflammatory and immunosuppressant effects (Deshmukh, 2007). The use of prednisone can be done in nursing mothers (Damiani et al., 2001);

- Methylprednisolone: An intermediate-acting GC, is four to five times more potent than hydrocortisone as well as prednisone (Zoorob; Cender, 2000). It has less mineralocorticoid activity than prednisone/prednisolone while having a similar duration of action and may be preferred when mineralocorticoid effect is particularly undesirable. An alternate day regimen should be considered during long-term therapy (Deshmukh, 2007). The use of methylprednisolone can be done in nursing mothers, only in low dose (less than $8 \mathrm{mg} /$ day) and the child should be breastfed after 4 hours of taking the GC (Damiani et al., 2001);

- Triamcinolone: An intermediate-acting GC, five times more potent than hydrocortisone can be done in nursing mothers (Damiani et al., 2001); 
- Dexamethasone: Is a long-acting GC (biological half-life of 36-72 hours) highly potent, available as oral, parenteral, topical (spray), and ophthalmic dosage forms (Cevc; Blume, 2004). Its potency is about 25 times greater than the short-acting products (Zoorob; Cender, 2000). This GC has minimal mineralocorticoid activity and is used most often in the management of acute disorders because prolonged treatment is associated with severe suppression of the HPA axis. Furthermore it's not suitable for alternate day regimens where the aim is to maintain the responsiveness of the HPA axis (Deshmukh, 2007);

- Betamethasone: Similar to dexamethasone, is unsuitable for long-term alternate-day therapy due to its long duration of action (Deshmukh, 2007).

The therapeutic dosing regimen of these agents is very wide and depends on the indication for treatment. The basis for the use of different dosages in different clinical conditions is essentially empirical. Thus, the appropriate dose for a specific therapeutic effect should be determined by trial and error as well as should be reassessed periodically, particularly when complications arise during a therapy (Buttgereit et al., 2002)

\subsection{Drug Interactions}

GCs are known substrates and inducers of cytochrome P450 3A (CYP3A), enzymes which constitute the major phase one drug-metabolizing enzyme family in humans (Anglicheau et al., 2003). Thus, drugs that inhibit CYP 3A4, such as erythromycin, clarithromycin, ketoconazole, itraconazole, act to reduce serum levels of GC, consequently increasing the incidence and severity of side effects of GCs. On the other hand, drugs that induce CYP 3A4, such as barbiturates, phenytoin, rifampin, act to reduce serum levels, consequently decreasing the activity of several systemic GCs (Pereira et al., 2007).

These agents are also known substrates and inducers of P-glycoprotein (P-gp), product of the multidrugresistance gene responsible for the transmembrane efflux of many drugs. P-gp reduces the intracellular concentration of various xenobiotics. The high dose steroid therapy was recently shown to lower tacrolimus blood levels in the rat, as a result of the induction of P-gp and CYP3A in the intestine and liver (Anglicheau et al., 2003).

Other drug interactions, which involve other mechanisms, are described below (Table 4):

\begin{tabular}{|ccc|}
\hline Drug & Mechanism of drug interaction & Consequence \\
\hline Estrogens & $\uparrow$ half-life and $\downarrow$ clearance of GCs & $\uparrow$ action of GCs \\
\hline Antacids & $\downarrow$ absorption of GCs & $\downarrow$ action of GCs \\
\hline Cholestyramine & $\downarrow$ absorption of GCs & $\downarrow$ action of GCs \\
\hline Ephedrine & $\begin{array}{c}\downarrow \text { half-life and increased clearance of GCs, } \\
\text { particularly of dexamethasone }\end{array}$ & $\downarrow$ action of GCs \\
\hline Cyclosporine & $\begin{array}{c}\text { Inhibition of metabolism of cyclosporine by } \\
\text { prednisolone }\end{array}$ & $\uparrow$ action of cyclosporine \\
\hline Isoniazid & $\downarrow$ level serum of isoniazid by GCs & $\downarrow$ action of isoniazid \\
\hline Salicylates & $\uparrow$ clearance of salicylates by GCs & $\downarrow$ action of salicylates \\
\hline Digitalics & GC-induced hypokalemia may $\uparrow$ serum & concentration of digitalics \\
\hline
\end{tabular}

Table 4. GC interactions and clinical consequences (Pereira et al., 2007; Anti et al., 2008) 


\section{New anti-inflammatory agents}

Nowadays, the increasing research developments in the fields of chemistry, pharmacology and molecular modeling, among others, share a common purpose: the pursuit and design of new agents and therapeutic targets. In this context, one area has raised interest in the field of therapeutic innovation: the treatment of inflammatory diseases.

Although its high therapeutic power, the anti-inflammatory therapies on the market have a high incidence of side effects resulting from its use (especially chronic), making unfavorable the risk/benefit ratio of these medications in many patients. Given this context, it becomes necessary to introduce new therapeutic options with more effective, specific and with fewer adverse effects actives. Currently, several targets and agents are being tested for their antiinflammatory activity, such as:

- Components of signal transduction (e.g. NF-kB and mitogen-activated protein kinase such as p38 kinase and c-Jun N-terminal kinases - JNKs): Some of small molecules that inhibit p38 kinase are in the final stages of clinical trials (Kulkarni et al., 2006);

- Dual inhibitiors of COX-2 and 5-lipoxygenase (5-LOX): Various structural families of dual inhibitors have been designed and several compounds are currently undergoing pre-clinical or clinical development. By preventing the biosynthesis of both prostanoids and LTs, they are potent anti-inflammatory agents (Charlier \& Michaux, 2003);

- Proinflammatory cytokines: Given their central role in the regulation of inflammatory responses, cytokines are clearly appealing targets for therapeutic intervention. Emphasis has been placed on cytokines that are produced early in the inflammatory cascade such as TNF-a and IL-6. Therapeutics neutralizing these cytokines or their receptors are already on the market or in late-phase development (Kopf et al., 2010).

Recently, a new biological target for anti-inflammatory therapy has been identified: the peroxisome proliferator-activated receptors (PPAR). PPARs are ligand-activated transcription factors belonging to the nuclear receptor superfamily. This superfamily includes steroidal transcription factors, non-steroidal receptors, PPARs and liver $X$ receptor (LXR).

Three major subtypes of the receptor have been identified: PPAR- $\alpha$, PPAR- $\beta$ and PPAR- $\gamma$.

Originally, the PPAR activity was thought to be limited to lipid metabolism and glucose homeostasis, being the PPAR- $\gamma$ agonists (known as thiazolidinediones) commonly prescribed for the treatment of diabetes. Later studies showed that PPAR activation regulates other biological functions such as cell proliferation, differentiation and apoptosis (Moraes et al, 2006).

Several studies have showed that PPAR-a and PPAR- $\gamma$ inhibit the expression of inflammatory genes. All available data indicate that the activation of PPAR- $\alpha$ and PPAR- $\gamma$ modulates oxidative stress-sensitive pathways, NF- $\mathrm{KB}, \mathrm{AP}-1$, and signal transducers and activators of transcription (STAT). These findings strongly indicate the potential as therapeutic target sites of PPAR- $\alpha$ and PPAR- $\gamma$ in controlling the inflammatory process and age-related inflammatory diseases. In support of evidence on the role of PPAR-a in the suppression of NF- $\mathrm{kB}$ activity, PPAR- $\alpha$ agonists are shown to decrease production of proinflammatory mediators such as IL-6, IL-12, IL-1a, iNOS, and COX-2, which are associated with the decrease in NF- $\kappa B$ activation. 
Apart from its role as a transcription factor, PPAR- $\gamma$ also acts as a trans-repressor of macrophage inflammatory genes. Ligand-independent activation of PPAR- $\beta / \delta$ can suppress bowel disease by down regulation of inflammatory signaling (Chung et al., 2008).

During inflammatory responses, PPARs can be activated by eicosanoids. Ligands for PPARY include leukotriene B4, 8(S)-hydroxyecosatetraenoic acid (HETE), 15-deoxy-D-12,14prostaglandin J2, 15-HETE and 13-hydroxyoctadecadienoic acid. Nuclear receptors can regulate macrophage gene expression in response to changes in cellular lipids and arachidonic acid metabolites that occur during inflammatory responses (Rizzo \& Fiorucci, 2006).

PPAR- $\gamma$ protein was identified in the antigen presenting cells, monocytes and macrophages and synthetic PPAR- $\gamma$ agonists including pioglitazone, troglitazone and rosiglitazone were shown to suppress production of inflammatory cytokines by these cells (Jiang et al., 1998; Ricote et al., 1998). Subsequently, PPAR-ץ was identified in dendritic cells. The same thiazolidinedione compounds were demonstrated to decrease dendritic cell secretion of IL12, a potent TH1-type inflammatory cytokine (Martin, 2010).

In this context, PPAR- $\gamma$ agonists have been investigated for their anti-inflammatory effects. Beneficial effects of the PPAR- $\gamma$ activator, rosiglitazone, were reported in two recent clinical trials for the treatment of Ulcerative Colitis (Lewis et al., 2008; Liang \& Ouyang, 2008). Animal models of inflammation are now being used to explore the utility of PPAR- $\gamma$ agonists in other inflammatory diseases.

\section{Conclusion}

The steroidal and non-steroidal anti-inflammatory drugs provide efficient therapies for the treatment of inflammatory diseases. However, several adverse effects related to acute and especially cronic use of such drugs limit its use in some patients. Thus, the clinician should take into account the risks and benefits of treatment for the patient before starting the therapy.

Recent searches for new targets and anti-inflammatory agents aim to attend the demand for new secure and equally efficient therapies for the treatment of inflammation. In this context, PPAR- $\gamma$ agonists appear as candidates for anti-inflammatory drugs.

\section{References}

ADAPT Research Group (2008). Cognitive function over time in the Alzheimer's Disease Anti-inflammatory Prevention Trial (ADAPT): Results of a randomized, controlled trial of naproxen and celecoxib. Arch Neurol, Vol.65, pp.896-905.

Akama, T.; Baker, S.J.; Zhang, Y.K.; Hernandez, V.; Zhou, H.; Sanders, V.; Freund, Y.; et al. (2009). Bioorganic \& Medicinal Chemistry Letters Discovery and structure activity study of a novel benzoxaborole anti-inflammatory agent (AN2728) for the potential topical treatment of psoriasis and atopic dermatitis. Bioorganic $\mathcal{E}$ Medicinal Chemistry Letters, Vol.19, No.8, pp. 2129-2132. 
Anglicheau, D.; Flamant, M.; Martinez, F. \& Schlageter, M.H.; Cassinat, B.; Beaune, P. et al. (2003). Pharmacokinetic interaction between corticosteroids and tacrolimus after renal transplantation. Nephrology Dialysis Transplantation, Vol.18, pp. 2409-2414.

Anti, S.M.A.; Giorgi, R.D.N. \& Chahade, W.H. (2008). Steroidal antiinflammatory drugs: glucocorticoids. Einstein, Vol.6, No.(Supl 1), pp. 159-165.

Antman, E.M.; DeMets, D. \& Loscalzo, J. (2005). Cyclooxygenase inhibition and cardiovascular risk. Circulation, Vol. 112, pp. 759-770.

Antman, E.M.; Bennet, J.S.; Daugherty, A.; Furberg, C.; Roberts, H. \& Taubert, K.A. (2007) Use of nonsteroidal anti-inflamatory drugs: an update for clinicians: a scientific statement from the American Heart Association. Circulation, Vol. 115, No.12, pp. 1634-1642.

Arber, N., Eagle, C.J., Spicak, J., et al. (2006). Celecoxib for the prevention of colorectal adenomatous polyps. N. Engl. J. Med., Vol.355, pp. 885-95

Baldwin, A.S. (1996). The NF-kappa B and I kappa B proteins: new discoveries and insights. Annual review of immunology, Vol.14, pp. 649-683.

Barnes, P.J. \& Adcock, I.M. (2009). Glucocorticoid resistance in inflammatory diseases. Review Literature And Arts Of The Americas, Vol.373, pp.1905-1917.

Berenbaum F. (2004). COX-3: fact or fancy? Joint Bone Spine, Vol.71, No.6, pp.451-453.

Bertagnolli, M.M., Eagle, C.J., Zauber, A.G., et al. (2006). Celecoxib for the prevention of sporadic colorectal adenomas. N Engl J Med, Vol.355, pp. 873-84

Bresalier, R.S.; Sandler, R.S.; Quan, H.; Bolognese, J.A.; Oxegius, B.; Horgan, K. et al. (2006) Cardiovascular events associated with rofecoxib in a colorectal adenoma chemoprevention trial N Engl J Med, Vol.352, pp.1092-1102.

Buttgereit, F.; da Silva, J.A.P.; Boers, M.; Burmester, G.R.; Cutolo, M.; Jacobs, J.; Kirwan, J. et al. (2002). Standardised nomenclature for glucocorticoid dosages and glucocorticoid treatment regimens: current questions and tentative answers in rheumatology. Annals of the rheumatic diseases, Vol.61 No.8, pp. 718-722.

Cardozo, A.L.P.; Bolzani, F.C.B.; Stefani, M. \& Charlín, R. (2007). Terapéutica Uso sistêmico de corticosteróides: revisão da literatura. Med Cutan Iber Lat Amer, Vol.35 No.1, pp. 35-50.

Cevc, G. \& Blume, G. (2004). Hydrocortisone and dexamethasone in very deformable drug carriers have increased biological potency, prolonged effect, and reduced therapeutic dosage. Biochimica et Biophysica Acta, Vol.1663, pp. 61-73.

Cha, I.Y.; DuBois, R.N. (2007). NSAIDs and Cancer Prevention: Targets Downstream of COX-2. Annu Rev Med Vol.58, pp. 239-252.

Chaney, MA. (2002). Corticosteroids and Cardiopulmonary Bypass : A Review of Clinical Investigations. Chest, Vol.121, No.3, pp. 921-931.

Charlier, C. \& Michaux, C. (2003). Dual inhibition of cyclooxygenase-2 (COX-2) and 5lipoxygenase (5-LOX) as a new strategy to provide safer non-steroidal antiinflammatory drugs. European Journal of Medicinal Chemistry, Vol.38,No.7-8,pp.645659.

Chen, CC.; Rosenbloom, CL.; Anderson, DC. \& Manning, AM. (1995). Selective inhibition of E-selectin, vascular cell adhesion molecule-1, and intercellular adhesion molecule-1 
expression by inhibitors of I kappa B-alpha phosphorylation. Journal of immunology (Baltimore, Md. : 1950), Vol.155, No.7, pp. 3538-3545.

Chung, JH.; Seo, AY.; Chung, SW.; Kim, MK.; Leeuwenburgh, C.; Yu, BP. \& Chung, HY. (2008). Molecular mechanism of PPAR in the regulation of age-related inflammation. Ageing research reviews, Vol.7, No.2, pp. 126-136.

Collins, T.; Read, MA.; Neish, AS.; Wiiitley, MZ.; Whitley, MZ.; Thanos, D. \& Maniatis, T. (1995). Transcriptional regulation of endothelial cell adhesion molecules: NF-kappa B and cytokine-inducible enhancers. The FASEB journal: official publication of the Federation of American Societies for Experimental Biology, Vol.9, No.10, pp. 899-909.

Cuzzocrea, S.; Bruscoli, S.; Mazzon, E.; Crisafulli, C.; Donato, V. et al. (2008). Peroxisome Proliferator-Activated Receptor-a Contributes to the Anti-Inflammatory Activity of Glucocorticoids. Clinical and Experimental Medicine, Vol.73, No.2, pp. 323-337.

Damiani, D.; Kuperman, H.; Dichtchekenian, V. \& Setian, N. (2001). Repercussions of corticotherapy: the cost-benefit ratio. Pediatria, No.1, pp. 71-82.

Davenport, MS.; Cohan, RH.; Caoili, EM. \& Ellis, JH. (2010). Hyperglycemic consequences of corticosteroid premedication in an outpatient population. AJR. American journal of roentgenology, Vol.194, No.6, pp. W483-488.

De Nijs, RN. (2008). Glucocorticoid-induced osteoporosis: a review on pathophysiology and treatment options. Minerva Med, Vol.99 No.1, pp. 23-43.

De Paiva, CS. \& Pflugfelder, SC. (2008). Rationale for anti-inflammatory therapy in dry eye syndrome. Inflammation, Vol.71, pp. 89-95.

Derendorf, H. \& Meltzer, E. O. (2008). Review article Molecular and clinical pharmacology of intranasal corticosteroids: clinical and therapeutic implications. Allergy, Vol.63, pp. 1292-1300.

Deshmukh, CT. (2007) Minimizing side effects of systemic corticosteroids in children. Indian J Dermatol Venereol Leprol, Vol.73, pp. 218-221.

Farrell, RJ. \& Kelleher, D. (2003). Mechanism of Steroid Action and Resistance in Inflammation - Glucocorticoid resistance in inflammatory bowel disease. Journal of Endocrinology, Vol.178, pp. 339-346.

Feghali, CA.; Wright, TM. (1997). Cytokines in acute and chronic inflammation. Frontiers in bioscience : a journal and virtual library, Vol.2, pp. 12-26.

Fernandes, AM.; Cardoso, F.; Valera, P. \& Anselmo-Lima, WT. (2008). Mechanism of action of glucocorticoids in nasal polyposis. Rev Bras Otorrinolaringol, 74(2), 279-283.

Fingar, VH.; Taber, SW.; Buschemeyer, WC.; Ten Tije, A.; Cerrito, PB.; Tseng, M. et al. (1997). Constitutive and stimulated expression of ICAM-1 protein on pulmonary endothelial cells in vivo. Microvascular research, Vol.54, No.2, pp 135-44.

Fitzgerald, DA. (2004) Coxibs and cardiovascular disease. N Engl J Med. Vol.351, pp.1709 1711.

Flammer, J. R. \& Rogatsky, I. (2011). Minireview: Glucocorticoids in autoimmunity: unexpected targets and mechanisms. Mol Endocrinol, Vol.25, No.7, pp. 1075-1086.

Frank, PG. \& Lisanti, MP. (2008). ICAM-1: role in inflammation and in the regulation of vascular permeability. American journal of physiology. Heart and circulatory physiology, Vol.295, No.3, pp. H926-H927. 
Gilmore, TD. (2006). Introduction to NF-kappaB: players, pathways, perspectives. Oncogene, Vol.25, No.51, p. 6680-4.

Gladding, PA.; Webster, MWI.; Farrell, HB.; Zeng, ISL.; Park, R. \& Ruijne, N. (2008). The antiplatelet effect of six non-steroidal antiinflammatorydrugs and their pharmacodynamic interaction with aspirin in healthy volunteers. Am J Cardiol Vol.101, pp. 1060-1063.

Goodman, L. S.; Brunton, L. L. \& Chabner, B. (2010). Goodman \& Gilman's The pharmacological basis of therapeutics (p. 1808). McGraw-Hill Medical.

Graham, D.; Campen, D.; Hui, R.; Spence, M.; Cheethan, C.; Levy, G. et al. (2005) Risk of acute myocardial infarction and sudden cardiac death in patients treated with cyclo-oxygenase 2 selective and non-selective non-steroidal anti-inflammatory drugs: nested case-control study. The lancet on-line, Vol.365, pp. 475-481.

Grbović, L. \& Radenković, M. (2005). Therapeutic use of glucocorticoids and immunosuppressive agents. Srpski arhiv za celokupno lekarstvo, Vol.133, pp. 67-73.

Grosser, T.; Fries, S. \& FitzGerald, G.A. (2006). Biological basis for the cardiovascular consequences of COX-2 inhibition: therapeutic challenges and opportunities. The Journal of clinical investigation, Vol.116, No.1, pp. 4-15.

Guay-Woodford L.M. (1998). Bartter syndrome: Unraveling the pathophysiologic enigma. Am J Med, Vol. 105, pp.151-161.

Hagan, J.B.; Taylor, R.L. \& Singh, R.J. (2011). Assessment of synthetic glucocorticoids in asthmatic sputum. Allergy Rhinol, Vol.2 No.1, pp. 33-35.

Hofstadler G.; Tulzer G.; Altmann R.; Schmitt K.; Danford D.; Huhta JC. Spontaneous closure of the human fetal ductus arteriosus: a cause of fetal congestive heart failure.(1996) Am J Obstet Gynecol. Vol.174, No.3, pp. 879-883.

Holdgate A, Pollock T. (2004) Systematic review of the relative efficacy of non-steroidal antiinflammatory drugs and opioids in the treatment of acute renal colic. BMJ, Vol.328, No.7453, pp. 1401.

Hollis Eden Pharmaceutical Annual Report, 2007

Inotai, A.; Hankó, B.; Mészáros, Á. (2010). Trends in the non-steroidal anti-inflammatory drug market in six Central - Eastern European countries based on retail information y. Parmamacoepidemiology and Drug Safety, Vol.19, No.2, pp.183-190.

Jakubowski, J.A.; Vaillancourt R. \& Deykin D. (1988). Interaction of ethanol, prostacyclin, and aspirin in determining human platelet reactivity in vitro. Arteriosclerosis, Vol.8, pp. 436-441.

Jiang, C.; Ting, A. T. \& Seed, B. (1998). PPAR-gamma agonists inhibit production of monocyte inflammatory cytokines. Nature, Vol.391, No.6662, pp. 82-86.

Jungnickel P.W., Maloley P.A., Vander Tuin E.L., et al. (1997). Effect of two aspirin pretreatment regimens on niacin-induced cutaneous reactions. J Gen Intern Med, Vol.12, pp.591-596.

Keenan, R.T.; O’brien, W.R.; Lee, K.H.; Crittenden, D.B.; Fisher, M.C.; Goldfarm, D.S. et al. Prevalence of Contraindications and Prescription of Pharmacologic Therapies for Gout. (2011) The American journal of medicine, Vol.124, No.2, pp. 155-162.

Kopf, M.; Bachmann, M.F.; Marsland, B.J. (2010). Averting inflammation by targeting the cytokine environment. Nature reviews. Drug discovery, Vol.9, No.9, pp. 703-718. 
Kujubu, D.A.; Herschman, H.R. (1992). Dexamethasone inhibits mitogen induction of the TIS10 prostaglandin synthase/cyclooxygenase gene. J Biol Chem, No.267, No.12, pp. 7991-7994.

Kulkarni, R.G.; Achaiah, G.; Sastry, G.N. (2006). Novel targets for antiinflammatory and antiarthritic agents. Current pharmaceutical design, Vol.12, No.19, pp. 2437-54.

Kurth T.; Glynn R.J.; Walker A.M.; Chan K.A.; Buring J.E.; Hennekens C.H. \& Gaziano J.M. (2003). Inhibition of clinical benefits of aspirin on first myocardial infarction by nonsteroidal antiinflammatory drugs. Circulation; Vol.108, pp. 1191-1195.

Laine, L.; Curtis, SP.; Cryer, B.; Kaur, A.; Cannon, C. P. (2010). Risk factors for NSAIDassociated upper GI clinical events in a long-term prospective study of 34701 arthritis patients. Alimentary pharmacology \& therapeutics, Vol.32, No.10, pp. 12401248.

Lewis, J. D.; Lichtenstein, G. R.; Deren, J. J.; Sands, B. E.; Hanauer, S. B.; Katz, J. A.; Lashner, B.; et al. (2008). Rosiglitazone for active ulcerative colitis: a randomized placebocontrolled trial. Gastroenterology, Vol.134, No.3, pp. 688-695.

Liang, HL.; Ouyang, Q. (2008). A clinical trial of combined use of rosiglitazone and 5aminosalicylate for ulcerative colitis. World journal of gastroenterology: WJG, Vol.14, No.1, pp. 114-119.

Löwenberg, M.; Stahn, C.; Hommes, DW. \& Buttgereit, F. (2007). Novel insights into mechanisms of glucocorticoid action and the development of new glucocorticoid receptor ligands. Arthritis \& Rheumatism, Vol.73, pp. 1025-1029.

Maneechotesuwan, K.; Ekjiratrakul, W.; Kasetsinsombat, K.; Wongkajornsilp, A. \& Barnes, PJ. (2010). Statins enhance the anti-inflammatory effects of inhaled corticosteroids in asthmatic patients through increased induction of indoleamine 2, 3dioxygenase. Journal of Allergy and Clinical Immunology, Vol.126, No.4, pp. 754762.

Martin, H. (2010). Role of PPAR-gamma in inflammation. Prospects for therapeutic intervention by food components. Mutation Research/Fundamental and Molecular Mechanisms of Mutagenesis, Vol.690, No.1-2, pp. 57-63.

Maeda, A.; Tsuruoka, S.; Ushijima, K.; Kanai, Y.; Endou, H.; Saito, K.; Miyamoto, E. \& Fujimura, A. (2010). Drug interaction between celecoxib and methotrexate in organic anion transporter 3-transfected renal cells and in rats in vivo. European journal of pharmacology, Vol.640, No.1-3, pp. 168-171.

McAdam B.F., Catella-Lawson F., Mardini I.A., et al (1999). Systemic biosynthesis of prostacyclin by cyclooxygenase (COX)-2: The human pharmacology of a selective inhibitor of COX-2. Proc Natl Acad Sci U S A, Vol.96, pp. 272-277.

Meade, E.A.; Smith, W.L. \& DeWitt, D.L. (1993). Differential inhibition of prostaglandin endoperoxide synthase (cyclooxygenase) isozymes by aspirin and other nonsteroidal anti-inflammatory drugs. The Journal of biological chemistry, Vol.268,Vol.9,pp.6610-6614.

Melnikova, I. (2010). Pain market. Nature reviews. Drug discovery, Vol.9, No.8, pp. 589-590.

Menezes, G.B.; Cara, D.C. \& Rezende, RM. (2009). Anti-inflammatory drugs: Basic knowledge to a safe prescription. Odontol. clin.-cient, Vol.8, No.1, pp. 7-12. 
Moraes, L.A.; Piqueras, L. \& Bishop-Bailey, D. (2006). Peroxisome proliferator-activated receptors and inflammation. Pharmacology \& therapeutics, Vol.110, No.3, pp. 371-385.

Neeck, G.; Renkawitz, R. \& Eggert, M. (2002). Cytokines, Cellular \& Molecular Therapy, Vol.7, No.2, pp. 61-69.

Niedner, R. (2001). Therapie mit systemischen Glukokortikoiden. Hautarzt, Vol.52, pp. 10621072.

Olaison, G.; Sjödahl, R. \& Tagesson, C. (1990). Glucocorticoid treatment in ileal Crohn's disease: relief of symptoms but not of endoscopically viewed inflammation. Gut, Vol.31 No.3, pp. 325-328.

O'Neill, L.A.J. (2008). The interleukin-1 receptor/Toll-like receptor superfamily: 10 years of progress. Immunological reviews, Vol.226, pp. 10-18.

Paul-Clark, M.J.; Mancini, L.; Del Soldato, P.; Flower, R.J. \& Perretti, M. (2002). Potent antiarthritic properties of a glucocorticoid derivative, NCX-1015, in an experimental model of arthritis. Proceedings of the National Academy of Sciences of the United States of America, Vol.99, No.3, pp. 1677-1682.

Pountos, I.; Georgouli, T.; Howard, B. \& Giannoudis, P.V. (2011) Nonsteroidal antiinflammatory drugs: prostaglandins, indications, and side effects. International Journal of Interferon, Cytokine and Mediator Research, Vol.3, pp. 19-27.

Prasit, P. (1999). The discovery of rofecoxib, [MK 966, VIOXX®, 4-(4'-methylsulfonylphenyl)3-phenyl-2(5H)-furanone], an orally active cyclooxygenase-2 inhibitor. Bioorganic $\mathcal{E}$ Medicinal Chemistry Letters, Vol.9, No.13, pp. 1773-1778.

Rao, P.N.P. \& Knaus, E.E. (2008). Evolution of Nonsteroidal Anti-Inflammatory Cyclooxygenase ( COX ) Inhibition and Beyond Drugs ( NSAIDs ): J Pharm Pharmaceut Sci, Vol.11, No.2, pp. 81-110.

Ricote, M.; Li, A.C.; Willson, T.M.; Kelly, C.J. \& Glass, C.K. (1998). The peroxisome proliferator-activated receptor-gamma is a negative regulator of macrophage activation. Nature, Vol.391, No.6662, pp. 79-82.

Rizzo, G. \& Fiorucci, S. (2006). PPARs and other nuclear receptors in inflammation. Current opinion in pharmacology, Vol.6, No.4, pp. 421-427.

Robbins, S.L.; Kumar, V.; Abbas, A.K.; Cotran, R.S. \& Fausto, N. (2010). Robbins and Cotran pathologic basis of disease (p. 1450).

Rottier, B.L. \& Duiverman, E.J. (2009). Anti-inflammatory drug therapy in asthma. Clinical Immunology, Vol.10, pp. 214-219.

Kremers, H.M.; Reinalda, M.S.; Crowson, C.S.; Davis, J.M.; Hunder, G.G. \& Gabriel, S.E. (2007). Glucocorticoids and Cardiovascular and Cerebrovascular Events in Polymyalgia Rheumatica. Arthritis \& Rheumatism, Vol.57 No.2, pp. 279-286.

Salvarani, C.; Cantini, F.; Boiardi, L. \& Hunder, G.G. (2002). Polymyalgia Rheumatica and Giant-Cell Arteritis. N Engl J Med, Vol.347, PP. 261-271.

Secoli, S.R. (2010) Polifarmácia: interações e reações adversas no uso de medicamentos por idosos. Revista Brasileira de Enfermagem, Vol.63, No.1, pp. 136-140.

Seeling, C.B.; Maloley, P.A.; Campbell, J.R. (1990). Nephrotoxicity Associated with concomitant ACE inhibitor and NSAID therapy. Southern Medical Journal. Vol.83, No.10, pp. 1144-1148. 
Shiri, R.; Koskimäki, J.; Häkkinen, T.L.J.; Tammaela, A.; Auvinen, A.; Hakama, M. (2006) Effect of Nonsteroidal Anti-inflamatory Drug Use on the Incidence of Erectile Dysfunction. The Journal of Urology, Vol.175, pp. 1812-1816.

Siew, C.N.G.; Francis, K.L.C. (2010) NSAID-induced Gastrointestinal and Cardiovascular Injury. Curr Opin Gastroenterol, Vol.26, No.6, pp.611-617.

Swartz, S.L.; Dluhy, R.G. (1978) Corticosteroids: clinical pharmacology and therapeutic use. Drugs, Vol.16, pp. 238-255

Tanaka, K.I.; Suemasu, S.; Ishihara, T.; Tasaka, Y.; Arai, Y.; Misushima, T. (2009) Inhibition of both COX-1 and COX-2 and resulting decrease in the level of prostaglandins E2 is responsible for non-steroidal anti-inflammatory drug (NSAID)-dependent exacerbation of colitis. European Journal of Pharmacology, Vol.603, pp. 120-132.

Thomsen, O.O.; Cortot, A.; Jewell, D.; Wright, J.P.; Winter, T. et al. (1998). A comparison of budesonide and mesalamine for active Crohn's disease. International BudesonideMesalamine Study Group.The New England journal of medicine,Vol.339,No.6,pp.370374.

Timóteo, R.P. \& Dos Santos, D. S. F. de A. V. (2009). Physical activity against reduction of mass bone induced for glucocorticoids. ConScientiae Saúde, Vol.8, No.1, pp. 139144.

Topol, E.J. (2004) Failing the public health: rofecoxib, Merck, and the FDA. N Engl J Med. Vol.351, pp.1707-1709.

United States Food and Drug Administration [FDA], Center for Drug Evaluation and Research, U.S. Department of Health and Human Services. (2011) Approved Drug Products with Therapeutic Equivalence Evaluations, 31th ed. U.S. Department of Health and Human Services, Washington, D.C.

Vane, J.R. (2000). The fight against rheumatism: from willow bark to COX-1 sparing drugs. Journal of physiology and pharmacology: an official journal of the Polish Physiological Society, Vol.51, pp. 573-586.

Vane, JR. (1971). Inhibition of Prostaglandin Synthesis as a Mechanism of Action for Aspirin-like Drugs. Nature, Vol.231, No.25, pp. 232-235.

Waddell, W.R., Ganser, G.F., Cerise, E.J., Loughry, R.W. (1989). Sulindac for polyposis of the colon. Am J Surg Vol. 157, pp. 175-79

Waddell, W.R., Loughry, R.W. (1983). Sulindac for polyposis of the colon. J Surg Oncol Vol.24, pp.83-87

Winkelmayer, W.C.; Waikar, S.S., Mogun, H. \& Solomon D.H. (2008) Nonselective and cyclooxygenase-2-selective NSAIDs and acute kidney injury. Am J Med. Vol.121, No.12, p.1092-1098.

Worobec A.S. (2000); Treatment of systemic mast cell disorders. Hematol Oncol Clin North Am, Vol.14, pp.659-687.

Yeh, R.K.; Chen, J.; Jennie, L.; Williams, J.L.; Baluch, M.; Hundleym T.R.; Hundley, R.E.; Rosenbaum, R.E.; Srinivas, K.; Tragano, F.; Benardini, F.; Soldato, P.D.; Kashfi, K.; Rigas, B. (2004) NO-donating nonsteroidal antiinflammatory drugs (NSAIDs) inhibit colon cancer cell growth more Potently than traditional NSAIDs: a general pharmacological property? Biochemical Pharmacology Vol.67, pp. 2197-2205 
Zele, T.V.; Gevaert, P.; Holtappels, G.; Beule, A.; Wormald, P.J.; Mayr, S. et al. (2010). Oral steroids and doxycycline: Two different approaches to treat nasal polyps. Journal of Allergy and Clinical Immunology, Vol.125, No.5, pp. 1069-1076.

Zoorob, R.J. \& Cender, D. (1998). A different look at corticosteroids. American family physician, Vol.58, No.2, pp. 443-50. 


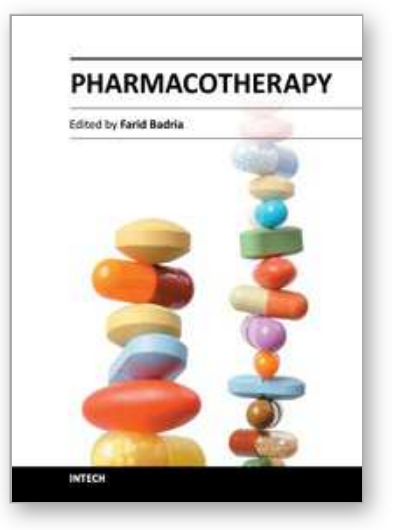

\author{
Pharmacotherapy \\ Edited by Dr. Farid Badria
}

ISBN 978-953-51-0532-9

Hard cover, 194 pages

Publisher InTech

Published online 29, June, 2012

Published in print edition June, 2012

The intent of this book is to provide an overview of current conceptualizations of Pharmacotherapy. The book focuses on three major areas; diagnosis, treatment, and prevention for a wide array of diseases; Cognitive and Psychological disorders (Schizophrenia and Nicotine addiction), Inflammatory disorders (New Chemical antiinflammatory and Immunotherapy), updated antihypertensive therapy and healing of ulcers with venous origin. A separate chapter is dedicated to the rationality of drug use in earthquake injuries. The last chapter deals with Imaging of potential therapeutic or diagnostic agents in animal models in the early stage of research. We hope this book is useful to a wide range of people, from students first learning about Pharmacotherapy, to advanced clinicians and researchers.

\title{
How to reference
}

In order to correctly reference this scholarly work, feel free to copy and paste the following:

Túlio Ricardo Couto de Lima Souza, Graziella Silvestre Marques, Amanda Carla Quintas de Medeiros Vieira and Juliano Carlo Rufino de Freitas (2012). State of the Art of Anti-Inflammatory Drugs, Pharmacotherapy, Dr. Farid Badria (Ed.), ISBN: 978-953-51-0532-9, InTech, Available from:

http://www.intechopen.com/books/pharmacotherapy/state-of-the-art-of-anti-inflammatory-drugs

\section{INTECH}

open science | open minds

\section{InTech Europe}

University Campus STeP Ri

Slavka Krautzeka 83/A

51000 Rijeka, Croatia

Phone: +385 (51) 770447

Fax: +385 (51) 686166

www.intechopen.com

\section{InTech China}

Unit 405, Office Block, Hotel Equatorial Shanghai

No.65, Yan An Road (West), Shanghai, 200040, China

中国上海市延安西路65号上海国际贵都大饭店办公楼405单元

Phone: $+86-21-62489820$

Fax: +86-21-62489821 
(C) 2012 The Author(s). Licensee IntechOpen. This is an open access article distributed under the terms of the Creative Commons Attribution 3.0 License, which permits unrestricted use, distribution, and reproduction in any medium, provided the original work is properly cited. 